\title{
OPTIMALISASI SHARI'A COMPLIANT ASSET PRICING MODEL TERHADAP RATE OF RETURN PADA JAKARTA ISLAMIC INDEX
}

\author{
Kharisya Ayu Effendi \\ Fakultas Manajemen dan Bisnis, Universitas Widyatama \\ Email : kharisya.ayu@widyatama.ac.id
}

\begin{abstract}
This study aimed to compare the three models SCAPM, namely SCAPM without risk free, SCAPM inflation and SCAPM zakat to know which model is more optimal use. The method used is the analysis of explanatory power and linear regression. The data used is secondary data, the inflation data, zakat, sharia shares incorporated in Jakarta Islamic Index (JII) from 2011 to 2015.The results are based on the analysis of explanatory power, SCAPM inflation is more optimal than SCAPM zakat and SCAPM without risk free. The results are supported by the results of the analysis graph illustrating SCAPM inflation has a higher volatility than other SCAPM, it indicates that the more profitable inflation SCAPM models are accompanied by greater risks, in accordance with the principles of the classical high risk high return.
\end{abstract}

Keyword: Shari'a Compliant Asset Pricing Model, Inflation, Zakat, Risk Free, Rate of Return

Abstrak: Penelitian ini bertujuan untuk membandingkan ketiga model SCAPM, yaitu SCAPM tanpa risk free, SCAPM inflasi dan SCAPM zakat untuk mengetahui model mana yang lebih optimal digunakan. Metode yang digunakan adalah analisis explanatory power dan menggunakan regresi linier. Data yang digunakan adalah data sekunder yaitu data inflasi, zakat, Saham syariah yang tergabung dalam Jakarta Islamic Indeks (JII) dari tahun 2011 hingga tahun 2015. Hasil yang diperoleh adalah berdasarkan hasil analisis explanatory power, SCAPM inflasi lebih optimal dibandingkan dengan SCAPM zakat dan SCAPM tanpa risk free. Hasil analisis tersebut didukung oleh hasil analisis grafik yang menggambarkan SCAPM inflasi memiliki volatilitas yang lebih tinggi dibanding SCAM lainnya, hal ini menandakan bahwa dengan model SCAPM inflasi lebih menguntungkan yang diiringi dengan resiko yang lebih besar, sesuai dengan prinsip klasik high risk high return.

Kata Kunci: Shari’a Compliant Asset Pricing Model, Inflasi, Zakat, Risk Free

\section{PENDAHULUAN}

Shari'a Compliant Asset Pricing Model( SCAPM) atau biasadikenal dengan Islamic CapitalAsset Pricing Model (ICAPM) merupakan modifikasi dari model analisis Capital Asset Pricing Model (CAPM) yang pada umumnya digunakan untuk memperdiksi tingkat resiko dan returnpada aset pricingyang diperkenalkan pertama kali oleh William Sharpe (1966) dan dikembangkan oleh Fama\&France (2003). Modifikasi model analisis ini merupakan salah satu bentuk dari menegakkanprinsip syariah yang sangat penting untuk diperhatikan dalam dunia saham yaitu keuntungan selalu disertai oleh resiko. Hal ini berarti bahwa tidak ada keuntungan yang dapat diperoleh tanpa diikuti oleh resiko. Konsep syariah 
ini sangat berlainan dengan konsep CAPM yang mengikutsertakan risk free rate kedalam modelnya yang dapat di representasikan secara matematis dibawah ini:

$$
R_{p}=R_{f}+\beta \cdot\left(R_{m}-R_{f}\right)
$$

( $R_{p}$ : Portofolio Return, ${ }^{R_{f}}$ : Risk Free, $\beta$ : Beta, $R_{m}$ : Market Return)

Dalam modifikasi CAPM menjadi SCAPM, peneliti satu dan yang lainnya memiliki argumen atau usulan yang berbeda. Seperti halnya Cyril dan Ri'fat (1987) mengusulkan bahwa SCAPM harus menghilangkan risk freedalam analisis matematis. Ditahun yang sama Ashker (1987) mengusulkan bahwa risk free tidak perlu dihilangkan , melainkan diganti dengan Zakat. Peneliti selanjutnya Sheikh (2010) mengusulkan bahwa sebaiknya pada model SCAPM ,risk free bukan diganti dengan Zakat, melainkan diganti dengan Nominal Produk Domestik Bruto (NGDP). Dan Muhammad Hanif ( 2010 ) mengusulkan bahwa dalam SCAPM risk free digantikan dengan Inflasi rate.

Perdebatan panjang antara peneliti satu dan yang lainnya menyebabkan belum ditetapkannya rumus matematis SCAPM yang paling tepat dalam menentukan prediksi return pada saham syariah. Dikarenakan hal ini, peneliti bertujuan untuk mengkomparasi dengan tiga model SCAPM diatas yaitu SCAPM tanpa risk free, SCAPM inflasi dan SCAPM Zakat untuk dapat mengetahui model mana yang lebih optimal digunakan untuk memprediksi return saham syariah di Indonesia. Penemuan pada penelitian ini diharapkan dapat memberikan manfaat kepada investor, manajer keuangan serta para akademisi.

\section{KAJIAN TEORI}

Capital Asset Pricing Model. Pada tahun 1964 CAPM dikembangkan oleh William Sharpe yang merupakan suatu model yang menghubungkan expected return dari suatu sekuritas berisiko dengan risiko dari sekuritas tersebut pada kondisi pasar yang seimbang.CAPM dikembangkan dengan mengikuti beberapa asumsi (Jogianto, 2010: 488) yaitu: (1) Semua investor melalukan pengambilan keputusan investasi berdasarkan pertimbangan antara nilai expected return dan standar deviasidari portofolio; (2) Semua investor mempunyai harapan yang homogen (homogenous expectations) terhadap faktor-faktor input yaitu return ekspektasi, varianreturn, dan kovarians antara return-return sekuritas untuk keputusan portofolio; (3) Semua investor dapat meminjamkan sejumlah dananya (lending) atau meminjam (borrowing) sejumlah dana dengan jumlah dana yang tidak terbatas pada tingkat suku bunga bebas risiko; (4) Penjualan pendek (short sale) diperkenankan dalam jumlah yang tak terbatas; (5) Asumsi tambahan yang digunakan pada data adalah; (6)Semua sekuritas dapat dipecah-pecah menjadi bagian yang lebih kecil dengan tidak terbatas; (7) Semua sekuritas dapat dijual dan dibeli di pasar dengan cepat (likuid) dengan harga yang berlaku; (8) Tidak terjadi inflasi; (9) Tidak adanya pajak bagi investor; (10) Tidak ada investor yang dapat mempengaruhi harga saham dengan kegiatan penjualan dan pembelian; (11) Pasar modal dalam kondisi seimbang (equilibrum). Semua investor akan memilih portofolio pasar dan portofolio pasar merupakan portofolio aktiva berisiko yang optimal yang berada di efficient frointer; (12) CAPM berdasarkan model markowitz yang masingmasing investor mengasumsikan akan mendiversifikasi portofolionya dan memilih 
portofolio optimal berdasarkan preferensi terhadap return dan risiko (Tandelilin, 2001). Secara umum, pembentukan portofolio CAPM berdasarkan persamaan sebagai berikut:

$$
\bar{R}_{k}=R_{f}+\beta_{k}\left(\bar{R}_{M}-R_{f}\right)
$$

dimana $: \bar{R}_{k}$ adalah expectedreturn portofolio, $R_{f}$ adalah return bebas risiko, $\bar{R}_{M}$ adalah expectedreturn portofolio pasar.

Pada titik keseimbangan investor mempunyai harapan yang sama terhadap return dan risiko, sehingga portofolio saham yang dipegang oleh seorang investor sama dengan investor lain dan membentuk portofolio pasar. Portofolio pasar merupakan portofolio yang semua berisi semua sekuritas yang ada di pasar. Proporsi semua saham dalam portofolio pasar semuanya berisi sekuritas berisiko. Untuk mengukur risiko pasar terhadap risiko portofolio dinyatakan dengan beta. Dalam keseimbangan pasar investor memegang portofolio yang terdiri dari sekuritas dengan portofolio pasar, jika risiko sistematik suatu sekuritas sama dengan risiko pasar maka beta portofolio investor sama dengan $1 . \beta=1$ menunjukkan jika return pasar bergerak naik, return sekuritas atau portofolio akan bergerak naik sama besarnya mengikuti return pasar. Untuk sekuritas dengan $\beta>1$ dikenal sebagai sekuritas agresif karena sekuritas tersebut bergerak lebih besar dari pada return pasar. Jika $\beta<1$ dikenal sebagai sekuritas difensive karena sekuritas tersebut bergerak lebih kecil dari pada return pasar. Beta saham ke-i dihitung menggunakan rumus:

$$
\beta_{i}=\frac{\operatorname{cov}\left(R_{i}, R_{M}\right)}{\operatorname{var}\left(R_{M}\right)}
$$

CAPM mengasumsikan investor memperhitungkan risiko dan keuntungan. Portofolio optimal dapat dibentuk investor dengan short sale yang diperbolehkan dan meminjamkan (lending) atau meminjam (borrowing) sejumlah dana dengan jumlah yang tidak terbatas pada tingkat suku bunga bebas risiko. Seorang investor akan sangat mungkin membentuk portofolionya dengan sekuritas berisiko dan sekuritas tidak berisiko.

Shari'a Compliant Asset Pricing Model. SCAPM diperkenalkan pertama kali oleh Cyril dan Ri'fat pada tahun 1987 dengan mengubah model CAPM dengan menghilangkan risk free didalam model tersebut. Model tersebut dapat di representasikan secara matematis dibawah ini :

$$
R_{p}=\beta \cdot R_{m}
$$

Hal ini dilakukan Cyril dan Ri'fat (1987) karena mereka beranggapan bahwa model SCAPM harus terbebas dari risk free karena menurut prinsip syariah, tidak ada keuntungan tanpa resiko. Sehingga mereka menilai setiap investasi pasti terdapat resiko, tidak ada investasi atau usaha yang bebas dari resiko.

Berbeda dengan Cyril dan Ri'fat, Ashker (1987) yang mengubah model CAPM dengan mengganti risk free dengan presentase Zakat yaitu 2,56\% (Presentase Zakat / 1- Presentase Zakat).

$$
R_{p}=Z+\left(R_{m}-Z\right) \beta
$$

Hal ini dikarenakan seorang muslim wajib mengeluarkan Zakat pada penghasilannya sebesar 2,5\% maka dari itu return bebas resiko yang ia yakini sebesar dengan presentase Zakat / 1 - 
presentase Zakat. Menurut Sheikh (2010) mengusulkan keterkaitan hutang dengan Nominal Gross Domestic Product (NGDP) atau Nominal Produk Domestik Bruto (NPDB) dan mengganti risk free dengan NGDP.

$$
R_{p}=N G D P+\left(R_{m}-N G D P\right) \beta
$$

Dimana menurutnya return investor tergantung pada dua komponen; tingkat pertumbuhan NGDP dan premi risiko diukur melalui beta yang berhubungan dengan tolak ukur. Muhammad Hanif (2011) mengusulkan risk free pada CAPM digantikan dengan inflasi rate.

$$
R_{p}=I+\left(R_{m}-I\right) \beta
$$

Hanif (2011) mengemukakan pandangan bahwa inflasi dapat digunakan sebagai variabel atauproxypenggantirisk free karena inflasi dapat dijadikan tolak ukur untuk melakukan investasitanpa tergantung dengan resiko. Dasar pandangan tersebut adalah variabel risk free yangselama ini digunakan menggunakan rate surat berharga (Indonesia menggunakan SBI rate), sedangkan rate surat berharga itu sendiri mengacu pada inflasi. Sehingga, variabel Rf sendiriterdiri dari dua komponen yaitu Real dan Inflation charge. Karena nilai riil dari Rftersebut mencerminkan timevalue of money, maka penggunaannya dilarang secara syariah,sedangkan belum ada pelarangan atas penggunaaninflation charge sehingga variabel tersebutdapat digunakan dalam memprediksiretun atas investasi.

\section{METODE}

Pada penelitian ini, analisis yang dilakukan adalah comparative explanatory powerpada tiga model SCAPM, untuk menentukan model paling optimaldalam memprediksi return dan resiko saham. Penelitian ini menggunakan data Inflasi, Zakat, dan perusahaan yang tergabung ke dalam Jakarta Islamic Indeks yang secara bertutut - turut konsisten selama periode Desember 2010 - Mei 2011 hingga periode Juni 2015 - November 2015, yaitu sebanyak 14 perusahaan yang konsisten secara berturut-turut selama 5 tahun di JII, yaitu AALI, ASII, ASRI, CPIN, INTP, ITMG, KLBF, LPKR, LSIP, PTBA, SMGR, TLKM, UNTR, UNVR. Return saham yang digunakan adalah data closing price pada 14 perusahaan tersebut secara daily (harian).

$$
\text { Return Saham } R_{i}=\frac{P_{t}-P_{t-1}}{P_{t-1}}
$$

$P_{t}$ : Harga saham hari ini, $P_{t-\mathbf{1}}$ : Harga saham pada hari sebelumnya

$$
\text { Rumus Beta } \beta=\frac{\operatorname{Cov} X, M}{\operatorname{Var} M}
$$

Metode analisis yang digunakanuntuk menentukan model terbaik dalam memprediksi return dan resiko pada keempat SCAPM adalah regresi Ordinary Least Square, yang dapat meregresi dengan baik apabila syarat BLUE ( Best Linier Unbiased Estimator )terpenuhi. Tahap pertama dari analisis ini adalah memastikan terpenuhinya asumsi-asumsiOLS yaitu data stasioner, tidak mengandung autokorelasi, dan tidak memilikimultikolinearitas agar memenuhi kriteri BLUE OLS. Uji stasionaritas menggunakan ujiADF-test, dan autokorelasi meggunakan stastistik run test.Kemudian menggunakan analisis grafik untuk memperkuat analisis data. 


\section{HASIL DAN PEMBAHASAN}

Tabel Statistik Descriptive. Berikut ini merupakan analisis statistik deskriptif SCAPM tanpa risk free (Cyril dan Ri'fat 1987), SCAPM risk free yang diganti dengan inflasi (M.Hanif 2010) dan SCAPM risk free yang diganti dengan zakat (Ashker 1987).

Tabel 1. Statistik Deskriptif SCAPM Tanpa Risk Free

\begin{tabular}{|c|c|c|c|c|c|c|c|c|c|c|c|c|c|c|}
\hline & AALI & ASII & ASRI & CPIN & INTP & ITMG & KLBF & LPKR & LSIP & PTBA & SMGR & TLKM & UNTR & UNVR \\
\hline Mean & 0.002 & 0.006 & 0.012 & 0.011 & 0.007 & 0.008 & 0.006 & -0.003 & -0.003 & -0.001 & 0.001 & 0.000 & 0.028 & 0.000 \\
\hline Median & 0.005 & 0.015 & 0.028 & 0.026 & 0.001 & 0.001 & 0.001 & 0.000 & 0.000 & 0.000 & 0.002 & 0.000 & 0.002 & 0.000 \\
\hline Maximum & 0.031 & 0.083 & 0.158 & 0.147 & 0.054 & 0.058 & 0.044 & 0.003 & 0.002 & 0.002 & 0.048 & 0.004 & 0.395 & 0.001 \\
\hline Minimum & -0.036 & -0.098 & -0.185 & -0.173 & -0.001 & -0.001 & -0.002 & -0.042 & -0.047 & -0.008 & -0.069 & 0.000 & 0.000 & -0.005 \\
\hline Std. Dev. & 0.016 & 0.045 & 0.084 & 0.079 & 0.013 & 0.013 & 0.010 & 0.008 & 0.008 & 0.002 & 0.019 & 0.001 & 0.065 & 0.001 \\
\hline Skewness & -0.769 & -0.769 & -0.769 & -0.769 & 1.923 & 1.950 & 1.875 & -2.816 & -3.157 & -2.267 & -0.833 & 6.151 & 3.645 & -6.082 \\
\hline Kurtosis & 2.798 & 2.798 & 2.798 & 2.798 & 5.804 & 5.991 & 5.916 & 11.807 & 14.497 & 7.868 & 6.482 & 42.97 & 19.03 & 42.86 \\
\hline Jarque-Bers & 5.918 & 5.918 & 5.918 & 5.918 & 55.69 & 59.381 & 55.466 & 268.63 & 422.96 & 108.79 & 36.628 & 4299 & 762.1 & 4270 \\
\hline Probability & 0.052 & 0.052 & 0.052 & 0.052 & 0.000 & 0.000 & 0.000 & 0.000 & 0.000 & 0.000 & 0.000 & 0.000 & 0.000 & 0.000 \\
\hline Sum & 0.140 & 0.378 & 0.716 & 0.669 & 0.436 & 0.451 & 0.339 & -0.191 & -0.193 & -0.041 & 0.042 & 0.008 & 1.629 & -0.005 \\
\hline Sum So.Dex. & 0.016 & 0.115 & 0.412 & 0.360 & 0.009 & 0.010 & 0.006 & 0.004 & 0.004 & 0.000 & 0.021 & 0.000 & 0.245 & 0.000 \\
\hline Observations & 59 & 59 & 59 & 59 & 59 & 59 & 59 & 59 & 59 & 59 & 59 & 59 & 59 & 59 \\
\hline
\end{tabular}

Tabel 2. Statistik Deskriptif SCAPM Inflasi

\begin{tabular}{|c|c|c|c|c|c|c|c|c|c|c|c|c|c|c|}
\hline & AALI & ASII & ASRI & CPIN & INTP & ITMG & KLBF & LPKR & LSIP & PTBA & SMGR & TLKM & UNTR & UNVR \\
\hline Mean & 0.038 & 0.001 & -0.050 & -0.043 & -0.052 & -0.045 & -0.056 & -0.059 & -0.073 & -0.078 & -0.003 & -0.079 & 0.023 & -0.070 \\
\hline Median & 0.041 & 0.009 & -0.031 & -0.025 & -0.032 & -0.026 & -0.033 & -0.027 & -0.034 & -0.028 & 0.000 & -0.028 & 0.002 & -0.028 \\
\hline Maximum & 0.066 & 0.079 & 0.102 & 0.099 & 0.105 & 0.101 & 0.109 & 0.093 & 0.101 & 0.085 & 0.002 & 0.085 & 0.319 & 0.084 \\
\hline Minimum & -0.009 & -0.105 & -0.277 & -0.254 & -0.294 & -0.270 & -0.330 & -0.401 & -0.509 & -0.614 & -0.047 & -0.639 & 0.000 & -0.435 \\
\hline Std. Dev. & 0.017 & 0.045 & 0.089 & 0.083 & 0.092 & 0.086 & 0.100 & 0.110 & 0.131 & 0.146 & 0.008 & 0.149 & 0.052 & 0.127 \\
\hline Skewness & -0.529 & -0.771 & -0.754 & -0.757 & -0.779 & -0.783 & -0.848 & -1.208 & -1.322 & -1.626 & -3.141 & -1.678 & 3.608 & -1.282 \\
\hline Kurtosis & 2.970 & 2.805 & 2.851 & 2.847 & 2.901 & 2.902 & 3.022 & 3.718 & 4.153 & 5.162 & 14.368 & 5.426 & 18.777 & 3.535 \\
\hline Jacque-Bera & 2.755 & 5.936 & 5.647 & 5.689 & 5.999 & 6.058 & 7.065 & 15.605 & 20.456 & 37.486 & 414.72 & 42.141 & 739.91 & 16.862 \\
\hline Pcobabil ity & 0.252 & 0.051 & 0.059 & 0.058 & 0.050 & 0.048 & 0.029 & 0.000 & 0.000 & 0.000 & 0.000 & 0.000 & 0.000 & 0.000 \\
\hline Sum & 2.221 & 0.087 & -2.929 & -2.509 & -3.044 & -2.630 & -3.301 & -3.466 & -4.319 & -4.591 & -0.191 & -4.664 & 1.355 & -4.149 \\
\hline Sum Squdexe & 0.017 & 0.116 & 0.458 & 0.397 & 0.494 & 0.429 & 0.579 & 0.698 & 0.988 & 1.234 & 0.004 & 1.286 & 0.159 & 0.938 \\
\hline Observations & 59 & 59 & 59 & 59 & 59 & 59 & 59 & 59 & 59 & 59 & 59 & 59 & 59 & 59 \\
\hline
\end{tabular}

Sumber: Data di olah menggunakan eviews 92016 
Tabel 3. Statistik Deskriptif SCAPM Zakat

\begin{tabular}{|c|c|c|c|c|c|c|c|c|c|c|c|c|c|c|}
\hline & AALI & ASII & ASRI & CPIN & INTP & ITMG & KLBF & LPKR & LSIP & PTBA & SMGR & TLKM & UNTR & UNVR \\
\hline Mean & 0.018 & 0.004 & -0.015 & -0.012 & 0.013 & 0.016 & 0.015 & 0.004 & -0.007 & -0.005 & -0.078 & 0.001 & 0.028 & 0.024 \\
\hline Median & 0.021 & 0.012 & 0.001 & 0.002 & 0.026 & 0.002 & 0.002 & 0.001 & 0.000 & 0.000 & -0.028 & 0.002 & 0.002 & 0.002 \\
\hline Maximum & 0.046 & 0.081 & 0.131 & 0.124 & 0.146 & 0.127 & 0.117 & 0.017 & 0.005 & 0.004 & 0.085 & 0.048 & 0.401 & 0.269 \\
\hline Minimum & -0.021 & -0.100 & -0.212 & -0.196 & -0.163 & -0.002 & -0.002 & -0.002 & -0.106 & -0.080 & -0.618 & -0.069 & 0.000 & 0.000 \\
\hline Std. Dev. & 0.016 & 0.045 & 0.084 & 0.079 & 0.076 & 0.029 & 0.026 & 0.006 & 0.019 & 0.014 & 0.146 & 0.019 & 0.066 & 0.050 \\
\hline Skewness & -0.769 & -0.769 & -0.769 & -0.769 & -0.747 & 2.018 & 2.029 & 1.193 & -3.144 & -3.396 & -1.634 & -0.865 & 3.679 & 2.803 \\
\hline Kurtosis & 2.798 & 2.798 & 2.798 & 2.798 & 2.776 & 6.308 & 6.513 & 3.022 & 14.42 & 16.52 & 5.20 & 6.56 & 19.33 & 11.8 \\
\hline Jacque-Bera & 5.918 & 5.918 & 5.918 & 5.92 & 5.62 & 66.94 & 70.83 & 13.99 & 417.80 & 562.81 & 38.17 & 38.56 & 789.1 & 267 \\
\hline Probability & 0.052 & 0.052 & 0.052 & 0.052 & 0.060 & 0.000 & 0.000 & 0.001 & 0.000 & 0.000 & 0.000 & 0.000 & 0.000 & 0.000 \\
\hline Sum & 1.045 & 0.251 & -0.875 & -0.718 & 0.760 & 0.963 & 0.864 & 0.210 & -0.440 & -0.305 & -4.607 & 0.049 & 1.641 & 1.389 \\
\hline Sum Sq.Dex. & 0.016 & 0.115 & 0.412 & 0.360 & 0.335 & 0.049 & 0.040 & 0.002 & 0.021 & 0.011 & 1.244 & 0.021 & 0.250 & 0.146 \\
\hline Observations & 59 & 59 & 59 & 59 & 59 & 59 & 59 & 59 & 59 & 59 & 59 & 59 & 59 & \\
\hline
\end{tabular}

Sumber: Data di olah menggunakan eviews 92016

Unit Root Test. Untukmemastikan terpenuhinya asumsi-asumsiOLS dan membuktikan bahwa data yang digunakan telah stasioner, maka dibawah ini adalah hasil dari uji stasionaritas menggunakan ujiADF-test dan PP-test.

Tabel 4. Unit Root Test Group

Group unit root test: Summary

Series: AALI, AALI_I, AALI_Z, ASII, ASII_I, ASII_Z, ASRI, ASRI_I, ASRI_Z, CPIN, CPIN_I, CPIN_Z, INTP, INTP_I, INTP_Z, ITMB_Z, ITMG, ITMG_I, KLBF, KLBF_I, KLBF_Z, LPKR, LPKR_I, LPKR_Z, LSIP, LSIP_I, LSIP_Z, PTBA, PTBA_I, PTBA_Z, RM, SMGR, SMGR_I, SMGR_Z, TLKM, TLKM_I, TLKM_Z, UNTR, UNTR_I, UNTR_Z, UNVL, UNVR_I, UNVR_Z

Date: 08/25/16 Time: 19:0 $\overline{7}$

Sample: 159

Exogenous variables: Individual effects

User-specified lags: 1

Newey-West automatic bandwidth selection and Bartlett kernel

Balanced observations for each test

\begin{tabular}{|c|c|c|c|c|}
\hline Method & Statistic & Prob.** & $\begin{array}{c}\text { Cross- } \\
\text { sections }\end{array}$ & Obs \\
\hline \multicolumn{5}{|c|}{ Null: Unit root (assumes common unit root process) } \\
\hline Levin, Lin \& Chu $t^{*}$ & -10.7347 & 0.0000 & 43 & 2451 \\
\hline \multicolumn{5}{|c|}{ Null: Unit root (assumes individual unit root process) } \\
\hline Im, Pesaran and Shin W-stat & -25.2993 & 0.0000 & 43 & 2451 \\
\hline ADF - Fisher Chi-square & 758.450 & 0.0000 & 43 & 2451 \\
\hline PP - Fisher Chi-square & 1284.38 & 0.0000 & 43 & 2451 \\
\hline
\end{tabular}

** Probabilities for Fisher tests are computed using an asymptotic Chi -square distribution. All other tests assume asymptotic normality.

Sumber: Data di olah menggunakan eviews 92016 
Dari data diatas dapat disimpulkan dari 43 data yang diolah telah stasioner dengan dibuktikan oleh probabilitas dari ADF-Fisher Chi-Square $<0.05$ begitu juga dengan probabilitas PP-Fisher Chi-square 0.0000 yang kurang dari 0.05.

Hasil Uji Regresi Menggunakan OLS. Setelah dilakukan pengujian unit root, dan uji autokorelasi menggunakan run test dan hasilnya tidak terdapat masalah pada stasioner data maupun autokorelasi pada data yang diuji karena Asymp.Sig (2-tailed) > 0,05, maka dilakukan analisis regresi dengan Least Square, dengan hasil dibawah ini:

Tabel 4. SCAPM Tanpa Risk Free

\begin{tabular}{lcccccccccccccc}
\hline \multicolumn{1}{c}{ Deskripsi } & AALI & ASII & ASRI & CPIN & INTP & ITMG & KLBF & LPKR & LSIP & PTBA & SMGR & TLKM & UNTR & UNVR \\
\hline Prob F-Stat & 0.000 & 0.000 & 0.000 & 0.000 & 0.000 & 0.000 & 0.000 & 0.000 & 0.000 & 0.000 & 0.156 & 0.000 & 0.000 & 0.186 \\
Prob C & 0.271 & 0.099 & 0.680 & 0.302 & 0.000 & 0.000 & 0.000 & 0.000 & 0.000 & 0.000 & 0.933 & 0.004 & 0.000 & 0.232 \\
Prob Rm & 0.000 & 0.000 & 0.000 & 0.000 & 0.000 & 0.000 & 0.000 & 0.000 & 0.000 & 0.000 & 0.156 & 0.000 & 0.000 & 0.186 \\
R-squared & 1.000 & 1.000 & 1.000 & 1.000 & 0.636 & 0.642 & 0.507 & 0.690 & 0.646 & 0.764 & 0.035 & 0.293 & 0.578 & 0.031 \\
Adj R- & 1.000 & 1.000 & 1.000 & 1.000 & 0.629 & 0.636 & 0.498 & 0.685 & 0.640 & 0.760 & 0.018 & 0.281 & 0.570 & 0.014 \\
Squared & & & & & & & & & & & & & & \\
\hline
\end{tabular}

Sumber: Data di olah menggunakan eviews 92016

Tabel 5. SCAPM Inflasi

\begin{tabular}{lcccccccccccccc}
\hline \multicolumn{1}{c}{ Deskripsi } & AALI & ASII & ASRI & CPIN & INTP & ITMG & KLBF & LPKR & LSIP & PTBA & SMGR & TLKM & UNTR & UNVR \\
\hline Prob F-Stat & 0.000 & 0.000 & 0.000 & 0.000 & 0.000 & 0.000 & 0.000 & 0.000 & 0.000 & 0.000 & 0.000 & 0.000 & 0.000 & 0.000 \\
Prob C & 0.000 & 0.000 & 0.000 & 0.000 & 0.000 & 0.000 & 0.000 & 0.000 & 0.000 & 0.000 & 0.000 & 0.000 & 0.000 & 0.000 \\
Prob Rm & 0.000 & 0.000 & 0.000 & 0.000 & 0.000 & 0.000 & 0.000 & 0.000 & 0.000 & 0.000 & 0.000 & 0.000 & 0.000 & 0.000 \\
R-squared & $\mathbf{0 . 7 4 0}$ & $\mathbf{0 . 9 9 9}$ & $\mathbf{0 . 9 6 8}$ & $\mathbf{0 . 9 7 2}$ & $\mathbf{0 . 9 6 5}$ & $\mathbf{0 . 9 6 8}$ & $\mathbf{0 . 9 6 1}$ & $\mathbf{0 . 9 5 2}$ & $\mathbf{0 . 9 3 8}$ & $\mathbf{0 . 9 0 8}$ & $\mathbf{0 . 6 4 8}$ & $\mathbf{0 . 9 0 2}$ & $\mathbf{0 . 5 7 7}$ & $\mathbf{0 . 9 4 4 4}$ \\
Adj R-Squared & 0.735 & 0.999 & 0.967 & 0.971 & 0.964 & 0.967 & 0.960 & 0.951 & 0.936 & 0.906 & 0.642 & 0.900 & 0.569 & 0.943 \\
\hline
\end{tabular}

Data di olah menggunakan eviews 92016

Tabel 6. SCAPM Zakat

\begin{tabular}{lcccccccccccccc}
\multicolumn{1}{c}{ Deskripsi } & AALI & ASII & ASRI & CPIN & INTP & ITMG & KLBF & LPKR & LSIP & PTBA & SMGR & TLKM & UNTR & UNVR \\
Prob F-Stat & 0.000 & 0.000 & 0.000 & 0.000 & 0.000 & 0.000 & 0.000 & 0.000 & 0.000 & 0.000 & 0.000 & 0.188 & 0.000 & 0.000 \\
Prob C & 0.000 & 0.000 & 0.000 & 0.000 & 0.000 & 0.000 & 0.000 & 0.000 & 0.000 & 0.000 & 0.000 & 0.885 & 0.000 & 0.000 \\
Prob Rm & 0.000 & 0.000 & 0.000 & 0.000 & 0.000 & 0.000 & 0.000 & 0.000 & 0.000 & 0.000 & 0.000 & 0.188 & 0.000 & 0.000 \\
R-squared & 1.000 & 1.000 & 1.000 & 1.000 & 1.000 & 0.653 & 0.606 & 0.270 & 0.647 & 0.619 & 0.907 & 0.030 & 0.574 & 0.661 \\
Adj R-Squared & 1.000 & 1.000 & 1.000 & 1.000 & 1.000 & 0.647 & 0.599 & 0.258 & 0.641 & 0.612 & 0.905 & 0.013 & 0.567 & 0.655
\end{tabular}

Data di olah menggunakan eviews 92016 
Perbandingan Signifikansi Model . Pada tabel 4.5 dengan menggunakanlevel of significance 95\%, terlihat bahwa modeltanpa risk free adalahsignifikan pada semua saham, kecuali saham SMGR dan UNVR, hal ini ditunjukkan dengan Prob F-stat yang melebihi alfa 0,05 yaitu SMGR 0,156 dan UNVR 0,186. Sementara pada tabel 4.6 SCAPM inflasi dengan menggunakanlevel ofsignificance95\%, terlihat bahwa modelSCAPMinflasi adalah signifikan pada semua saham. Dan Pada tabel 4.7 SCAPM zakat dengan menggunakanlevel ofsignificance95\%, semua saham signifikan kecuali TLKM dengan tingkat probabilitas 0,188 melebihi alfa 0,05. Dari data hasil regresi, dari 14 perusahaan hanya 11 perusahaan dengan keseluruhan model signifikan, sehinggahanya 11 saham tersebut yang akandibandingkan explanatory powernya.

Perbandingan Explanatory Power. Variabel independen penelitian ini hanya 1 yaitu $\mathrm{Rm}$ atau Return Market, maka kita dapat menggunakan R-squared untukmelihat dan membandingkanexplanatory power masing-masing model terhadap masing-masing saham. Untuk saham AALI, R-squared model pada model SCAPM tanpa risk free 1,0000sama dengan R-squared SCAPM Zakat, namun pada SCAPM inflasi R-squared lebih kecil sebesar 0,740. Pada saham ASII R-squared model pada model SCAPM tanpa risk free 1,0000sama dengan R-squared SCAPM Zakat, namun pada SCAPM inflasi R-squared sedikit lebih kecil sebesar 0,999. Pada saham ASRI R-squared model pada model SCAPM tanpa risk free 1,0000sama dengan R-squared SCAPM Zakat, namun pada SCAPM inflasi R-squared sedikit lebih kecil sebesar 0,968.Pada saham CPIN R-squared model pada model SCAPM tanpa risk free 1,0000sama dengan R-squared SCAPM Zakat, namun pada SCAPM inflasi R-squared sedikit lebih kecil sebesar 0,972.Sedangkan pada saham INTP model SCAPM tanpa risk freeR-squared hanya sebesar 0,636 , R-squared model SCAPM inflasi tetap stabil 0,965 dan SCAPM zakat tetap 1,0000..Secara keseluruhan data yang digambarkan pada tabel diatas dapat ditarik kesimpulan bahwa sebagian besar saham dalam ketiga model memilikiexplanatory power yang besar. Hal ini ditunjukkan dengan nilai koefisien Rsquaredyang menunjukkan seberapa besar variasi pada independen variabel dapat menjelaskanvariasi pada dependen variabel. Hasilnya, explanatory power tidak dapat dijelaskan pada masing - masing saham secara langsung karena banyak kesamaan antara model satu dan yang lainnya, namun, apabila dilihat dari kestabilan hasil maka model SCAPM dengan Inflasi memiliki hasil yang optimal dan memiliki rata-rata R-squared yang terbesar yaitu 0,889 sementara SCAPM tanpa risk free hanya 0,630 dan SCAPM dengan zakat sebesar 0,712. Sehingga bila di tarik kesimpulan menurut explanatory power SCAPM inflasi lebih optimal. 


\section{a. Analisis Grafik}

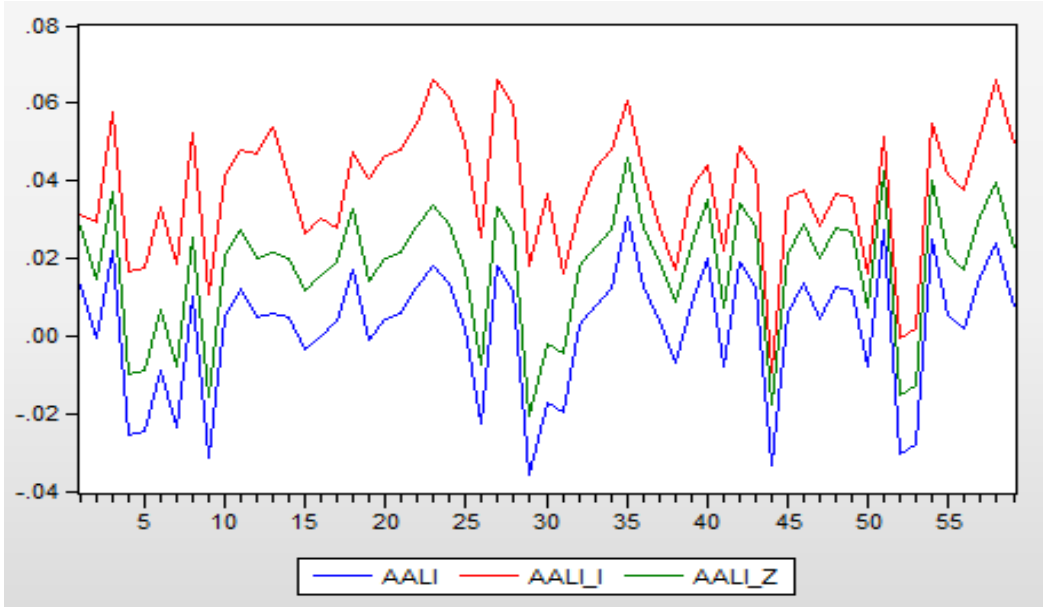

Gambar 1. Grafik Perbandingan Model SCAPM pada Saham AALI

Data di olah menggunakan eviews 92016

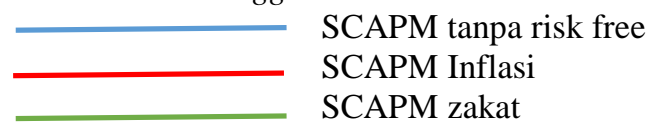

Pada Grafik 1 diatas menggambarkan volatilitas pada saham AALI dengan tiga model yaitu biru tanpa risk free, merah dengan inflasi dan hijau dengan zakat memiliki volatilitas yang sama. Hal ini berarti bahwa pada saham AALI ketiga model memiliki tingkat resiko dan return yang sama.

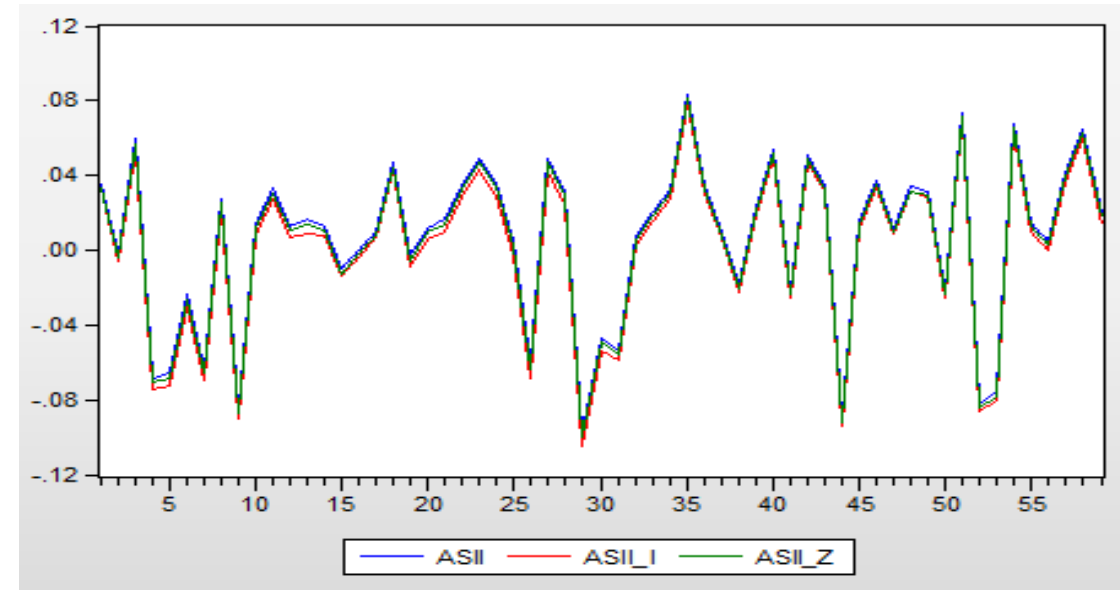

Gambar 2. Grafik Perbandingan Model SCAPM pada Saham ASII

Pada Grafik 2 diatas menggambarkan volatilitas pada saham ASII dengan tiga model yaitu biru tanpa risk free, merah dengan inflasi dan hijau dengan zakat memiliki volatilitas yang 
sama. Hal ini berarti bahwa pada saham ASII ketiga model memiliki tingkat resiko dan return yang sama.

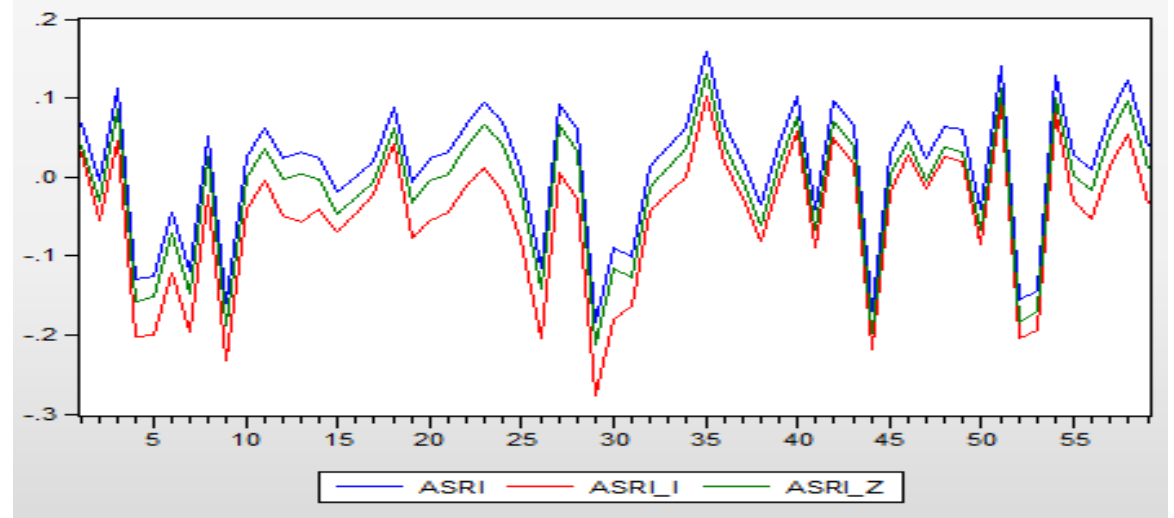

Gambar 3. Grafik Perbandingan Model SCAPM pada Saham ASRI

Pada Grafik 3 diatas menggambarkan volatilitas pada saham ASRI dengan tiga model yaitu biru tanpa risk free, merah dengan inflasi dan hijau dengan zakat memiliki volatilitas yang sama. Hal ini berarti bahwa pada saham ASRI ketiga model memiliki tingkat resiko dan return yang sama.

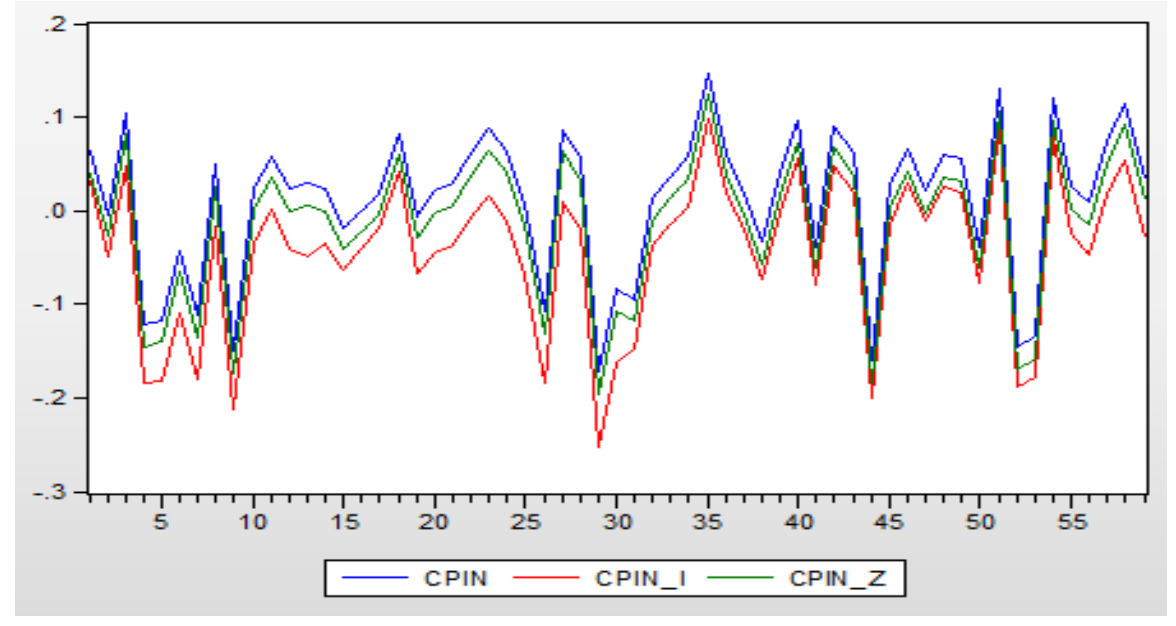

Gambar 4. Grafik Perbandingan Model SCAPM pada Saham CPIN

Pada Grafik 4 diatas menggambarkan volatilitas pada saham CPIN dengan tiga model yaitu biru tanpa risk free, merah dengan inflasi dan hijau dengan zakat memiliki volatilitas yang sama. Hal ini berarti bahwa pada saham CPIN ketiga model memiliki tingkat resiko dan return yang sama. 


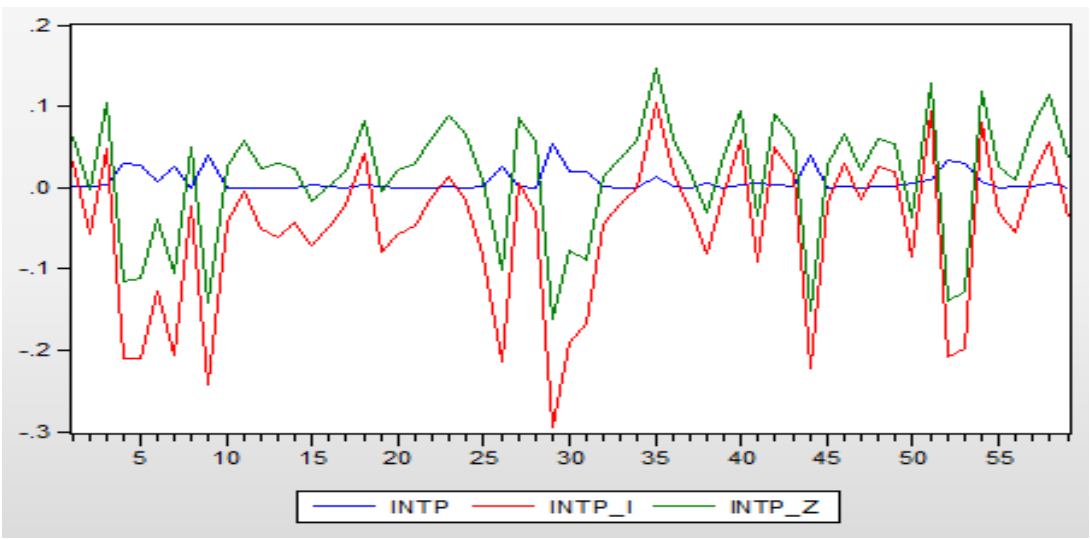

Gambar 5. Grafik Perbandingan Model SCAPM pada Saham INTP

Pada grafik 4.5 diatas menggambarkan volatilitas pada saham INTP dengan tiga model yaitu biru tanpa risk free, merah dengan inflasi dan hijau dengan zakat memiliki volatilitas yang berbeda, yaitu inflasi lebih volatile dibandingkan tanpa risk free yang stabil. Hal ini berarti bahwa pada saham INTP model SCAPM inflasi memiliki tingkat resiko dan return yang lebih tinggi.

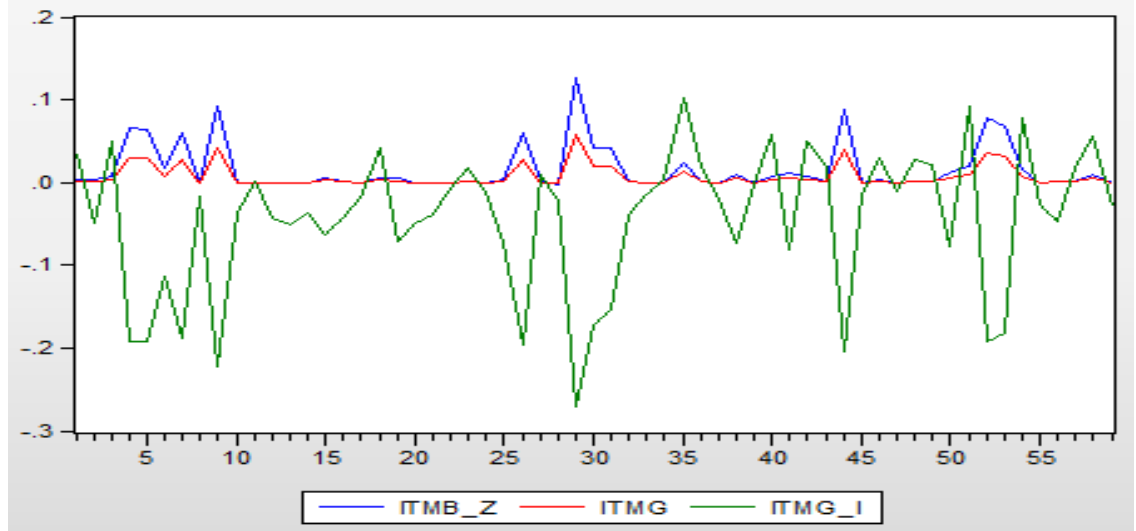

Gambar 6. Grafik Perbandingan Model SCAPM pada Saham ITMG

Pada Grafik 6 diatas menggambarkan volatilitas pada saham ITMG dengan tiga model yaitu biru zakat, merah tanpa risk freedan hijau inflasimemiliki volatilitas yang berbeda, yaitu inflasi lebih volatile dibandingkan tanpa risk freedan zakat yang stabil. Hal ini berarti bahwa pada saham ITMG model SCAPM inflasi memiliki tingkat resiko dan return yang lebih tinggi. 


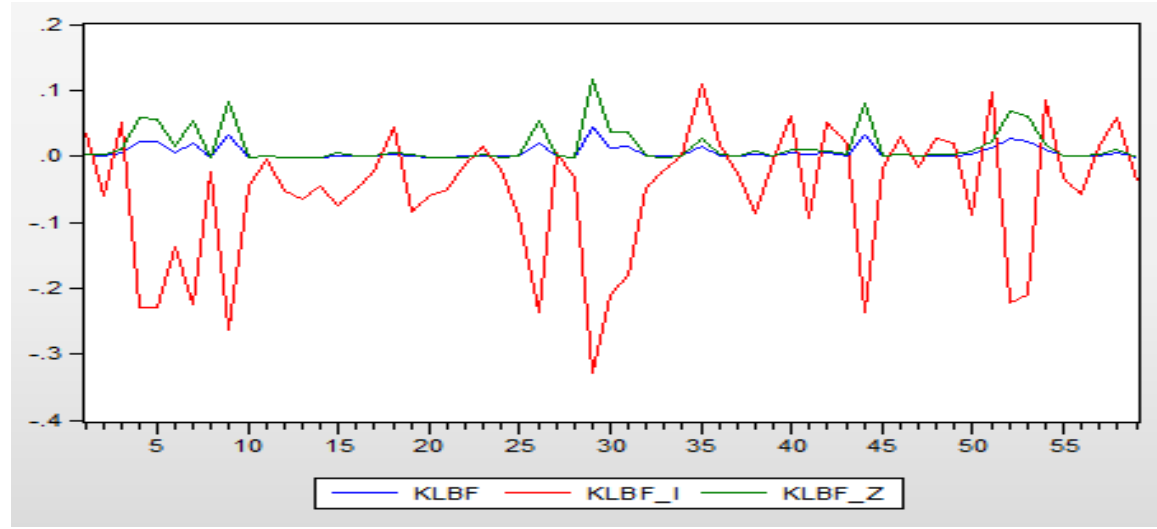

Gambar 7. Grafik Perbandingan Model SCAPM pada Saham KLBF

Pada grafik 4.7 diatas menggambarkan volatilitas pada saham KLBF dengan tiga model yaitu biru tanpa risk free, merah dengan inflasi dan hijau dengan zakat memiliki volatilitas yang berbeda, yaitu inflasi lebih volatile dibandingkan tanpa risk freedan zakat yang stabil. Hal ini berarti bahwa pada sahamKLBF model SCAPM inflasi memiliki tingkat resiko dan return yang lebih tinggi.

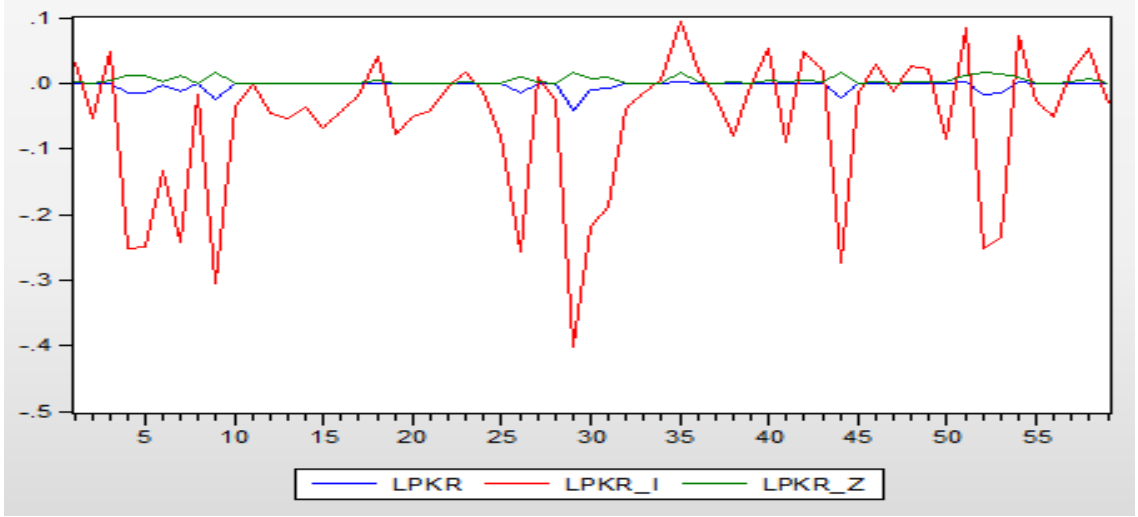

Gambar 8. Grafik Perbandingan Model SCAPM pada Saham LPKR

Pada grafik 4.8 diatas menggambarkan volatilitas pada saham LPKR dengan tiga model yaitu biru tanpa risk free, merah dengan inflasi dan hijau dengan zakat memiliki volatilitas yang berbeda, yaitu inflasi lebih volatile dibandingkan tanpa risk freedan zakat yang stabil. Hal ini berarti bahwa pada sahamLPKR model SCAPM inflasi memiliki tingkat resiko dan return yang lebih tinggi. 
Ayu: Optimalisasi Shari'a A Compliant Asset Pricing Model Terhadap Rate of Return:...

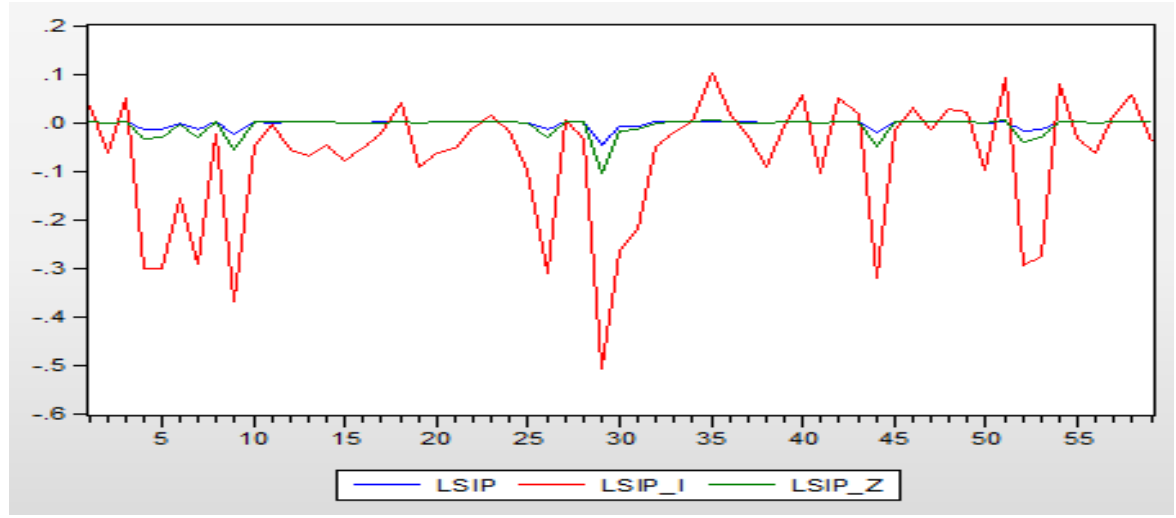

Gambar 9. Grafik Perbandingan Model SCAPM pada Saham LSIP

Pada grafik 4.9 diatas menggambarkan volatilitas pada saham LSIP dengan tiga model yaitu biru tanpa risk free, merah dengan inflasi dan hijau dengan zakat memiliki volatilitas yang berbeda, yaitu inflasi lebih volatile dibandingkan tanpa risk free dan zakat yang stabil. Hal ini berarti bahwa pada saham LSIP model SCAPM inflasi memiliki tingkat resiko dan return yang lebih tinggi.

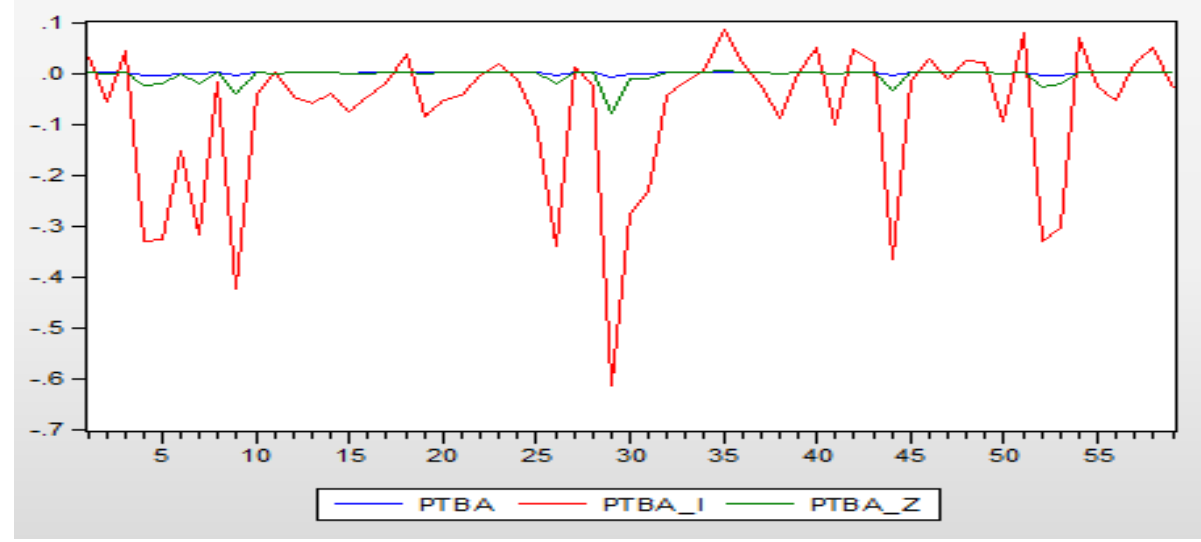

Gambar 10. Grafik Perbandingan Model SCAPM pada Saham PTBA

Pada grafik 4.10 diatas menggambarkan volatilitas pada saham PTBA dengan tiga model yaitu biru tanpa risk free, merah dengan inflasi dan hijau dengan zakat memiliki volatilitas yang berbeda, yaitu inflasi lebih volatile dibandingkan tanpa risk freedan zakat yang stabil. Hal ini berarti bahwa pada sahamPTBA model SCAPM inflasi memiliki tingkat resiko dan return yang lebih tinggi. 


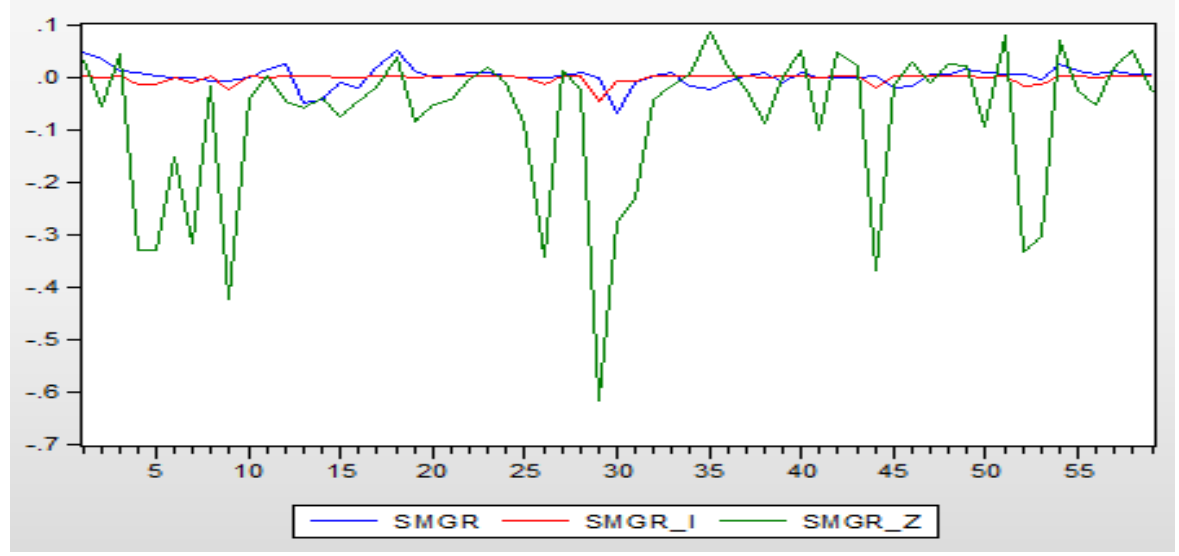

Gambar 11. Grafik Perbandingan Model SCAPM pada Saham SMGR

Pada grafik 4.11 diatas menggambarkan volatilitas pada saham SMGR dengan tiga model yaitu biru tanpa risk free, merah dengan inflasi dan hijau dengan zakat memiliki volatilitas yang berbeda, yaitu zakat lebih volatile dibandingkan tanpa risk freedan inflasi yang stabil. Hal ini berarti bahwa pada sahamSMGR model SCAPM zakatmemiliki tingkat resiko dan return yang lebih tinggi.

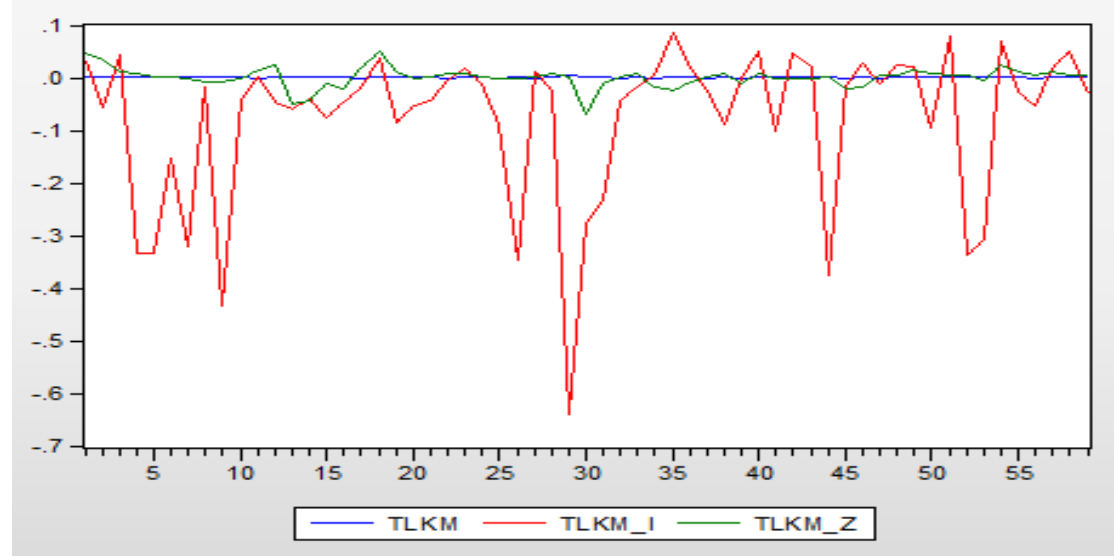

Gambar 12. Grafik Perbandingan Model SCAPM pada Saham TLKM

Pada grafik 12 diatas menggambarkan volatilitas pada saham TLKMdengan tiga model yaitu biru tanpa risk free, merah dengan inflasi dan hijau dengan zakat memiliki volatilitas yang berbeda, yaitu inflasi lebih volatile dibandingkan tanpa risk free dan zakat yang stabil. Hal ini berarti bahwa pada sahamTLKM model SCAPM inflasi memiliki tingkat resiko dan return yang lebih tinggi. 


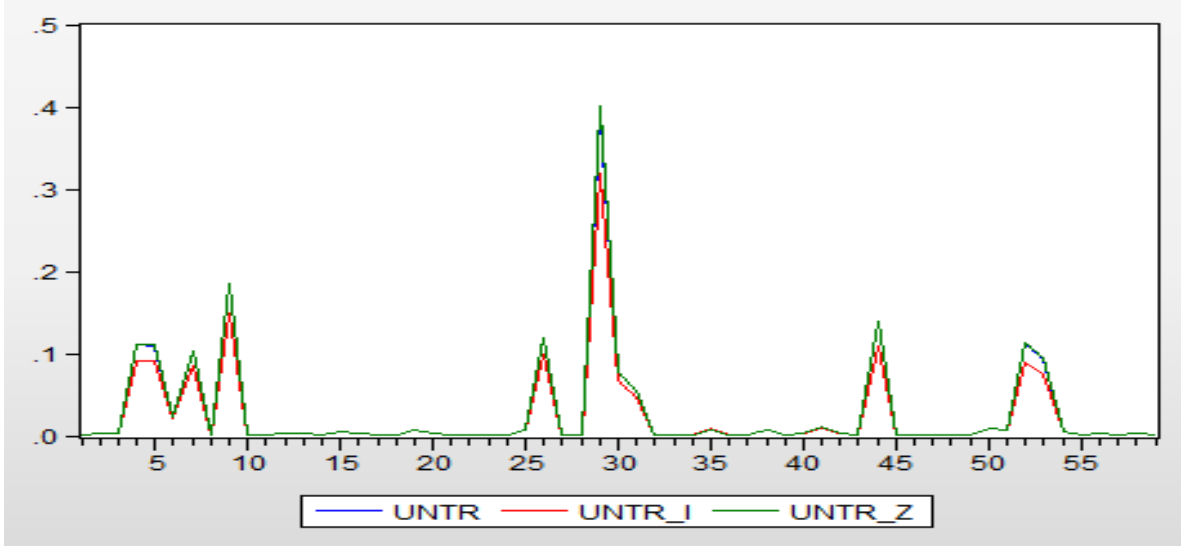

Gambar 13. Grafik Perbandingan Model SCAPM pada Saham UNTR

Pada Grafik 13 diatas menggambarkan volatilitas pada saham UNTR dengan tiga model yaitu biru tanpa risk free, merah dengan inflasi dan hijau dengan zakat memiliki volatilitas yang sama. Hal ini berarti bahwa pada saham UNTRketiga model memiliki tingkat resiko dan return yang sama.

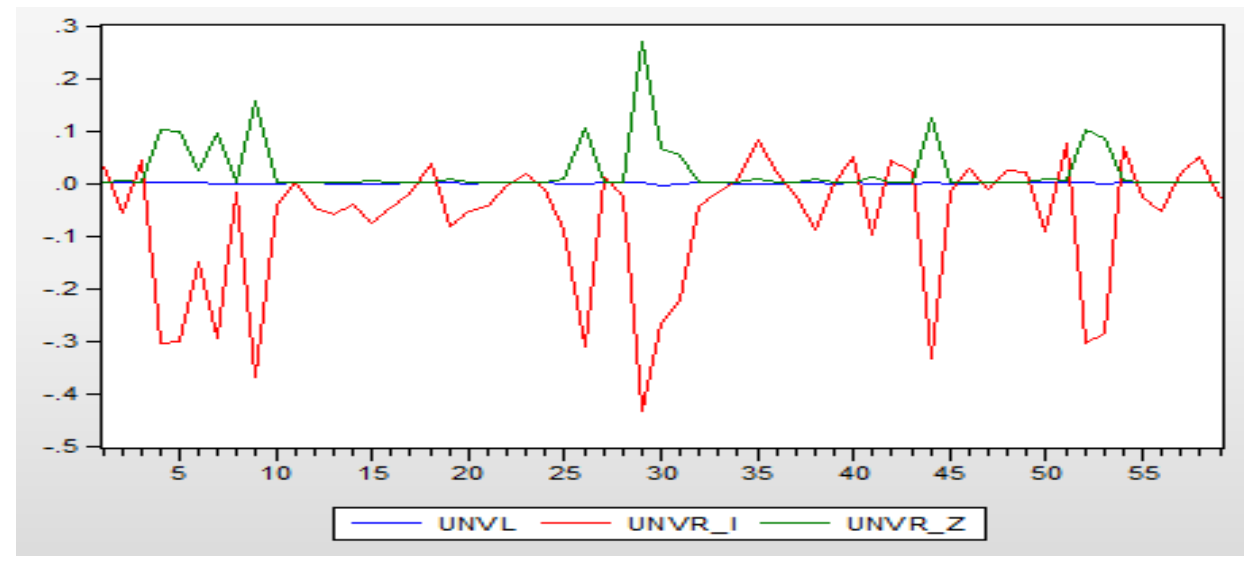

Gambar 14. Grafik Perbandingan Model SCAPM pada Saham UNVR

Pada Grafik 14 diatas menggambarkan volatilitas pada saham UNVR dengan tiga model yaitu biru tanpa risk free, merah dengan inflasi dan hijau dengan zakat memiliki volatilitas yang berbeda, yaitu inflasi lebih volatile dibandingkan tanpa risk free dan zakat yang stabil. Hal ini berarti bahwa pada sahamUNVR model SCAPM inflasi memiliki tingkat resiko dan return yang lebih tinggi.

Hasil kesimpulan dari grafik diatas menggambarkan dimana data telah dihitung sesuai dengan rumus yang digunakan pada setiap model SCAPM kemudian di interpretasikan kedalam grafik. Grafik diatas merupakan gambaran setiap saham dengan membandingkan ketiga model SCAPM. Hasil yang diperoleh dari gambaran grafik diatas adalah beberapa saham mengalami volatilitas yang sama seperti AALI,ASII, ASRI, CPIN dan UNTR. Namun, sebagian besar saham menunjukan volatilitas yang berbeda seperti 
INTP, ITMG, KLBF, LPKR, LSIP, PTBA, SMGR, TLKM, dan UNVR. Volatilitas yang digambarkan lebih voletile pada SCAPM inflasi dan volatilitas stabil digambarkan oleh SCAPM tanpa risk free. Hal ini menggambarkan bahwa, model dengan volatilitas tinggi lebih beresiko tinggi dibandingkan dengan volatilitas rendah. Namun, hal ini sesuai dengan prinsip high risk high return , dengan resiko yang tinggi sejalan dengan keuntungan yang akan didapatkan. Hasil penelitian ini sejalan dengan Sadaf dan Andleeb (2014) SCAPM inflasi lebih bervoletile dibandingkan dengan SCAPM tanpa risk free. Mereka berpendapat bahwa SCAPM inflasi dengan model CAPM dengan risk free memiliki volatilitas yang sama, hal ini dinyatakan bahwa model SCAPM yang dimodifikasi dengan mengganti risk free dengan inflasi menyelamatkan umat islam dari larangan agama dan tetap mendapatkan keuntungan dan kerugian yang sama dengan investor lainnya (non investasi syariah).

\section{PENUTUP}

Simpulan. Hasil yang diperoleh adalah berdasarkan hasil analisis explanatory power, SCAPM inflasi lebih optimal dengan rata-rata R-square 0,889 dibandingkan dengan SCAPM zakat 0,712 dan SCAPM tanpa risk free dengan R-square 630. Hasil rata-rata ini diambil karena tidak ada R-square yang lebih dominan dari masing - masing saham pada setiap model, namun model yang paling optimal menunjukkan kestabilan data. Hasil analisis tersebut didukung oleh hasil analisis grafik yang menggambarkan SCAPM inflasi memiliki volatilitas yang lebih tinggi dibanding SCAM lainnya, hal ini menandakan bahwa dengan model SCAPM inflasi lebih menguntungkan yang diiringi dengan resiko yang lebih besar, sesuai dengan prinsip klasik high risk high return.Hasil penelitian ini sejalan dengan Sadaf dan Andleeb (2014) SCAPM inflasi lebih bervoletile dibandingkan dengan SCAPM tanpa risk free. Mereka berpendapat bahwa SCAPM inflasi dengan model CAPM dengan risk free memiliki volatilitas yang sama, hal ini dinyatakan bahwa model SCAPM yang dimodifikasi dengan mengganti risk free dengan inflasi menyelamatkan umat islam dari larangan agama dan tetap mendapatkan keuntungan dan kerugian yang sama dengan investor lainnya (non investasi syariah).Sejalan dengan Hanif (2011) yangmengemukakan pandangan bahwa inflasi dapat digunakan sebagai variabel atauproxypenggantirisk free karena inflasi dapat dijadikan tolak ukur untuk melakukan investasitanpa tergantung dengan resiko.Model yang optimal ditemukan pada SCAPM inflasi ini apabila digunakan untuk mendapatkan rate of return yang lebih maksimal. Saran bagi investor yang ingin berinvestasi pada pasar modal, model ini dapat menjadi rujukan agar mendatkan keuntungan lebih maksimal.

\section{DAFTAR RUJUKAN}

Ashker, A.A.F (1987) Islamic Business Enterprise, Croom Helm Limited, Provident House, Burell row Backenham, Cant.

Cyril, T and Ri'fat, K (1987) The Shari'ah and Its Implications for Islamic Financial Analysis:AnOpportunity to Study Interactions Among Society, Organization and Accounting. The American Journal of Islamic Social Sciences, 4(1), 101-115.

Eduardus, Tandelilin (1997) Deteminant of Systematic Risk: The Experience of SomeIndonesia Common Stock, Kelola, 16 (IV): 101-114. 
Fama,E.F., \& French, K. R (2003) The CAPM: Theory and evidence.Center for Research in Security Prices (CRSP) University of Chicago Working Paper, (550).

Hakim, S., \& Rashidian, M (2002) Risk and return of Islamic stock market indexes.In $9^{\text {th }}$ Economic Research Forum Annual Conference in Sharjah, UAE on October 26 (Vol. 28).129.

Hanif, M (2011)Risk and Return under Shari’a Framework: An Attempt to Develop Shari'a Compliant Asset Pricing Model (SCAPM). Pakistan Journal of Commerce and Social Sciences, 5(2).

Hanif, M \& Dar, A (2011) Comparative Testing of Capital Asset Pricing Model (CAPM) andShari'a Compliant Asset Pricing Model (SCAPM): Evidence from Karachi Stock Exchange Pakistan. Middle Eastern Journal of Scientific Research, Forthcoming.

Iqbal, Z (2002) Portfolio Choices and Asset Pricing in Islamic Framework. Theoretical of Islamic Economics, 167.

Jogiyanto, Hartono (2010) Edisi Ketujuh. Teori Portofolio dan Analisis Investasi.Yogyakarta : BPFE

Kahf, M (2003) Islamic economics: notes on definition and methodology. Review of Islamic Economics, 23-48.

Sadaf , R and Andleeb, S (2014) Islamic Capital Asset Pricing Model (ICAPM) Journal of Islamic Banking and Finance, Vol. 2, No. 1, pp. 187-195

Selim, T. H (2008) An Islamic capital asset pricing model. Humanomics, 24(2),122- 12. Economics Project Publication Co-Sponsored by University of East.

Sheikh, S.A (2010) Corporate Finance in an Interest free economy: An alternate approach to practiced Islamic Corporate finance

Sharpe, W. F (1966) Mutual fund performance. The Journal of Business, 39(1), 119-138 